\title{
SPONGE ROBOTIC HAND DESIGN FOR PROSTHESES
}

\author{
Mine Seçkin ${ }^{1}$ and Necla Yaman Turan ${ }^{1 *}$ \\ ${ }^{1}$ Uşak University Textile Engineering Department, Bir Eylül Kampüsü, Uşak 64100, \\ Turkey
}

ABSTRACT

In this study robotic hands and fingers' materials are investigated from past to present and a sponge robotic hand is designed for biomedical applications. Emergence and necessity of soft robotic technology are explained and description of soft robot is made. Because of the importance of hand in a person's body, researchers have dealt with robotic hand prostheses for many centuries and developed many hand types. To mimic the best for the human limbs, softness of the hand is one of the important features. Recent studies are summarized in a table. In the table you can see materials that are used in robotic hand and fingers; they are classified as soft and rigid with their years. In literature sponge was found as the most suitable material for the fingers, but there is no study about a sponge hand. This study aims to fill this gap in literature. In this paper manufacturing of a Sponge Robotic Hand's production parameters and stages are explained clearly. Finally advantages of sponge robotic hand and future studies about sponge robotic hand are mentioned.

\section{KEYWORDS}

Robotics; Soft robots, Robotic hand, Prosthese

\section{INTRODUCTION}

Hand is an important limb which is not used for only grasping, but also exploration, touch and perception of physical properties (roughness, pressure, temperature, weight, etc.) for human [1]. Therefore, researchers have dealt with robotic hand prostheses for many centuries. When the literature was examined, it was found that modern robotic hand is based on the history of 1970s. There are a lot of hand types in literature, firstly researchers studied on one finger, two finger and lately multi fingered hands. After providing the desired movement of the hands, researchers began to search for robotic materials which can mimic the best for the humanoid robots, especially robotic hand, arm and leg. These types of robots require soft and elastic materials to mimic flesh, skin and ligament. Usage of soft and elastic materials enabled a new field of robotics which is called soft robotic [2].

Many Soft Robots have been developed in order to be used in biomedical, defense, industrial, educational, media and emergency applications [3-5]. These robots consist of a combination of various elastic and soft materials in layers and cells [5,6]. Soft materials' advantages are; soft materials' high impact strength, shape change ability, hereby pass through tight space, working compatible with living tissues without any damaging etc. The compliance of the soft material helps conform to most uneven surfaces. Especially because of this feature of the soft materials, it is suitable for making robotic hands like a human hand with soft materials.

DOI: 10.5121/ijbes.2016.3402 
In literature, although there is an important study study about the sponge which is found the most suitable material for the fingers, there isn't any study about sponge hand. This study aims to fill this gap in literature. Sponge has a structure that is full of full of pores because of this structure it has a light weight and it is a durable material, it has a soft touch which is our preference reason. Therefore, we considered it is suitable to make a robotic hand with sponge.

\subsection{Related Works}

Shimoga and Goldenberg (1996) considered three main problems with the fingers. These are the impact forces while grasping a rigid object, a hand with hard fingers' grasping ability to objects that have uneven surfaces and the last problem is repetitive strains that are induced into the fingers. To overcome these problems they constructed six fingertips from plastic, rubber, sponge, fine powder, paste and gel and compared their ability. According to experimental results, sponge fingertip is the most suitable and plastic fingertip is the least suitable [7]. In their experiments, they mounted the tip at the end of an experimental finger that was a two link parallel bar robot manipulator built in-house and actuated by two direct drive motors. They placed a multi-axis force sensor at the end of the finger tip; they controlled the finger with a microprocessor and collected the sensory data at $50 \mathrm{~Hz}$ in all experiments.

According to these graphics they ranked overall comparison of the six materials in order of preferences in Table 1

Table 1. Overall Comparison of the six materials ranked in order of preference*[1].

\begin{tabular}{|c|c|c|c|c|}
\hline & \multicolumn{4}{|c|}{ Desired Properties (Criteria) } \\
\hline Material & $\begin{array}{l}\text { Impact Energy } \\
\text { Attenuation } \alpha \Psi\end{array}$ & $\begin{array}{c}\text { Surface } \\
\text { Conformability } \\
\beta \mp\end{array}$ & $\begin{array}{l}\text { Strain Energy } \\
\text { Dissipation VI }\end{array}$ & $\begin{array}{c}\text { Al three } \\
\text { Properties } \delta \mathbf{T} \\
(\alpha+\beta+\gamma)\end{array}$ \\
\hline Plastic & 6 & 6 & 6 & $6(18)$ \\
\hline Rubber & 3 & 5 & 3 & $4(11)$ \\
\hline Sponge & 1 & 1 & 1 & $1(3)$ \\
\hline Powder & 2 & 4 & 4 & $3(10)$ \\
\hline Paste & 5 & 3 & 5 & $5(13)$ \\
\hline Gel & 4 & 2 & 2 & $2(8)$ \\
\hline
\end{tabular}

*1 means most preferred, 6 means least preferred $f$ here $\alpha$ denotes the ranking if impact energy attenuation is the required criterion. Similarly, $\beta$ and $\gamma$ denote the rankings for conformability and strain energy dissipation, respectively $\delta$ denotes the overall ranking and is obtained by taking an equal weighted sum of $\alpha, \beta, \gamma$.

In this study we investigate the robotic hands' materials; we gave a general table about the robotic hands from 1996 to present day. Materials that are used in robotic hands are classified as soft and rigid, purpose of usage with its year is given in Table 2 .

According to the table, there are a lot of types of material that can be used in robotic hands and fingers. In recent years, it has been that softness has become important that mostly silicone rubber has been used and purpose of usage has become mostly prosthetic hand and rehabilitation. 
International Journal of Biomedical Engineering and Science (IJBES), Vol. 3, No. 4, October 2016

Table 1. Robotic hands and fingers from 1996 to present

\begin{tabular}{|c|c|c|c|c|c|}
\hline \multirow{2}{*}{ Robot type } & \multicolumn{2}{|c|}{ Materials } & \multirow{2}{*}{ Purpose of usage } & \multirow{2}{*}{ Year } & \multirow{2}{*}{ References } \\
\hline & Soft & Rigid & & & \\
\hline Graspar & No & Aluminum & Robotic applications & 1996 & [8] \\
\hline DeLaurentis & No & Aluminum & Grasping applications & 2000 & [9] \\
\hline Lotti \& Vassura & Nylon & $\begin{array}{l}\text { Teflon (PTFE), } \\
\text { Delrin( plastic } \\
\text { material) }\end{array}$ & Grasping applications & 2002 & [10] \\
\hline Wilkinson & No & $\begin{array}{l}\text { Molded cadaver } \\
\text { bones }\end{array}$ & Grasping applications & 2003 & [11] \\
\hline Lotti/UB Hand & $\begin{array}{l}\text { Soft } \\
\text { elastomeric } \\
\text { layer }\end{array}$ & Rigid hollow frame & Prosthetic hand & 2005 & [12] \\
\hline $\begin{array}{l}\text { Cabas/RL1 } \\
\text { Hand }\end{array}$ & No & Aluminum & $\begin{array}{l}\text { To help Elderly \& } \\
\text { disabled people }\end{array}$ & 2006 & [13] \\
\hline Takamuku & No & $\begin{array}{l}\text { Polyxinylidene } \\
\text { fluoride films } \\
\text { (PVDF) (plastic } \\
\text { material) }\end{array}$ & Robotic applications & 2007 & [14] \\
\hline Gosselin & $\begin{array}{l}\text { Rubber pad } \\
\text { coating }\end{array}$ & Plastic & Robotic applications & 2008 & [15] \\
\hline $\begin{array}{l}\text { Gaiser FRH-4 } \\
\text { hand }\end{array}$ & $\begin{array}{l}\text { Rubber } \\
\text { actuators }\end{array}$ & Aluminum & Industrial & 2008 & [16] \\
\hline Rosen & $\begin{array}{l}\text { Elastic rubber } \\
\text { coverings }\end{array}$ & Aluminum, metal & Prosthetic hand & 2009 & [17] \\
\hline Nagase & $\begin{array}{l}\text { Silicone } \\
\text { rubber }\end{array}$ & No & $\begin{array}{l}\text { Prosthetic \& } \\
\text { Rehabilitation hand }\end{array}$ & 2012 & [18] \\
\hline Belter \& Dollar & No & Acrylic & Prosthetic hand & 2013 & [19] \\
\hline $\begin{array}{l}\text { Deimel \& } \\
\text { Brock } / \text { RBO } \\
\text { hand }\end{array}$ & $\begin{array}{l}\text { Silicone } \\
\text { rubber }\end{array}$ & $\begin{array}{l}\text { Woven fabric, yam } \\
\text { (Polyester) }\end{array}$ & Grasping applications & 2013 & {$[20]$} \\
\hline $\begin{array}{l}\text { Polygerinos/ } \\
\text { rehabilitation } \\
\text { glove }\end{array}$ & $\begin{array}{l}\text { Silicone } \\
\text { rubber }\end{array}$ & No & Rehabilitation & 2013 & [21] \\
\hline $\begin{array}{l}\text { Galloway/ } \\
\text { Prostehetic } \\
\text { hand }\end{array}$ & $\begin{array}{l}\text { Silicone } \\
\text { rubber }\end{array}$ & $\begin{array}{l}\text { Kevlar yam, glass } \\
\text { fabric }\end{array}$ & Prosthetic hand & 2013 & [22] \\
\hline $\begin{array}{l}\text { Maeder-York/ } \\
\text { Rehabilitation }\end{array}$ & $\begin{array}{l}\text { Silicone } \\
\text { rubber }\end{array}$ & Woven fabric, yam & Rehabilitation & 2014 & [23] \\
\hline Al-Timemy & No & $\begin{array}{l}\text { Acrylonitrile } \\
\text { butadiene styrene } \\
\text { (ABS) }\end{array}$ & Prosthetic hand & 2014 & [24] \\
\hline Beir/RHI & $\begin{array}{l}\text { Silicone } \\
\text { rubber }\end{array}$ & Nylon wire, Springs & Prosthetic hand & 2014 & [25] \\
\hline
\end{tabular}

\section{DESIGN AND MANUFACTURING}

\subsection{Materials}

The study consists of five stages and in these stages sponge, glue, Kevlar yarn, guide actuator, servo motors and control circuit are combined. The other sponge robotic hand materials', features and preference reasons are respectively like this: 
* Kevlar is a para-aramid synthetic fiber. It has high tensile strength to weight ratio; by this measure it is five times stronger than steel [26]. It is an inelastic material, if it was an elastic material, system will require to do the settings again.

*Actuator Guide is a plastic tube which guides the Kevlar yarn's movement with minimum stick and friction.

*Mini servo motors are preferred, because they can be easily rotated to the desire angle. ES08 MAII mini servo motors are used for each finger. Its voltage is $4.8-6 \mathrm{~V}$, torque is $1.6 / 2.0 \mathrm{~kg} . \mathrm{cm}$, speed $0.12 / 0.10 \mathrm{~s} / 60^{\circ}$, its weight is $12 \mathrm{~g}$ and its dimensions are $23 \times 11.5 \times 24 \mathrm{~mm}$. Five servo motors are placed into a servo motor bearing. We made servo motor bearing with $3 \mathrm{~d}$ printer. And also we made pulley system for servo motors with $3 \mathrm{~d}$ printer (in Figure 1).

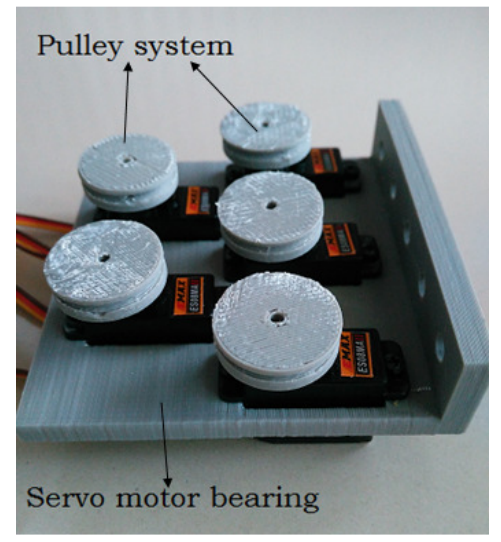

Figure 1.Servo motors in bearing with pulley system

Hot wire sponge cutter, scissors and scar are used for cutting and editing the sponge like a hand shape. We made two types of special hot wire sponge cutter for cutting guide channels smoothly. One of them is for cutting hand shape, the other is for cutting hollow cylindrical channels for guides.

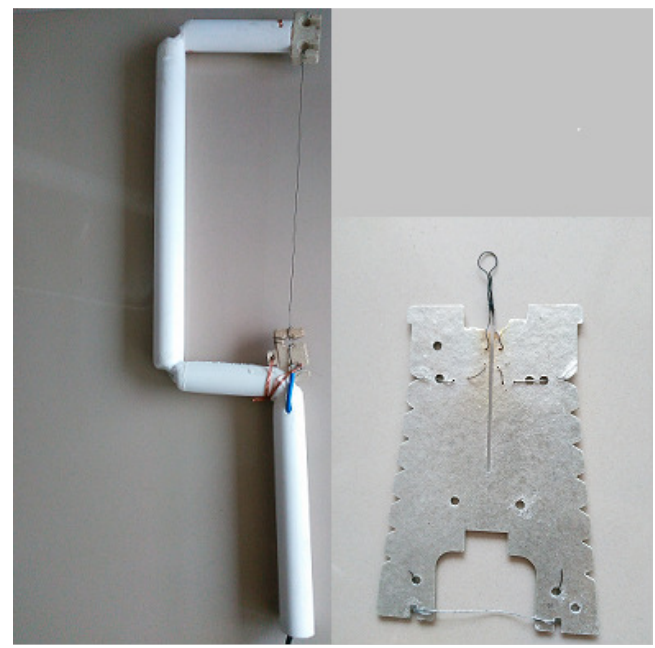

a

b

Figure 2. (a) Hot wire sponge cutter (For hand shape) (b) Hot wire sponge cutter for cylindrical channels 
International Journal of Biomedical Engineering and Science (IJBES), Vol. 3, No. 4, October 2016

\subsection{Manufacturing Stages}

1. Cutting and Shaping: Sponge is cutted into a hand form by a hot wire sponge cutter (In Figure 2(a)) smoothly. (Figure3)

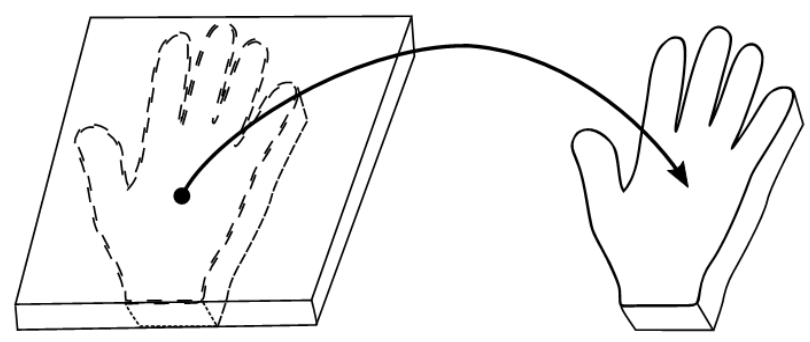

Figure 3 Cutting sponge hand

2. Opening deep guide channel: Cylindrical channel is for plastic tube guide. These channels are made by hot wire sponge cutter, as you can see in Figure 2(b), it is a special design for placing the guide in deep. (Figure 4)
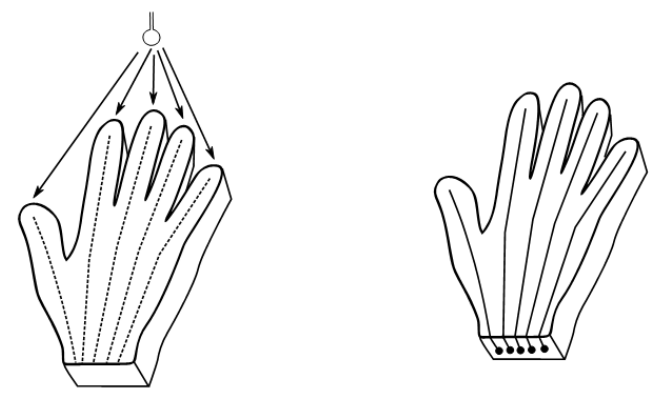

Figure 4. Formation of cylindrical hollow channel

3. Guide preparing and placement: A plastic tube guide is prepared like a finger bone. It has three parts, and three cutouts parts. Cutouts act like a joint of the finger. In sponge hand there is not any rigid joint. Kevlar yarn is placed into plastic tube. Guide with Kevlar yarn is placed into sponge hand. In figure 9, bending movement of the plastic tube guide with Kevlar is given. It is just like a bone of the fingers without any rigid joints. Finally placed guides are glued smoothly. (Figure 5)
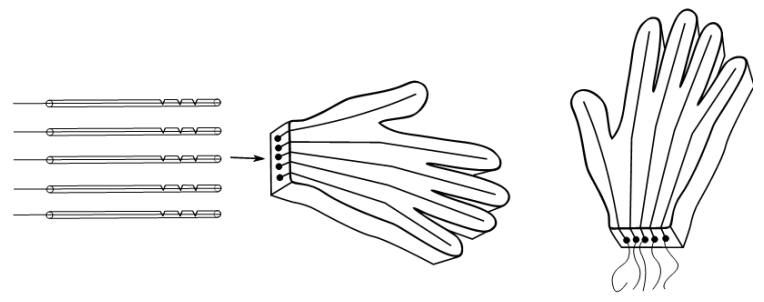

Figure 5. Line preparing and placement 


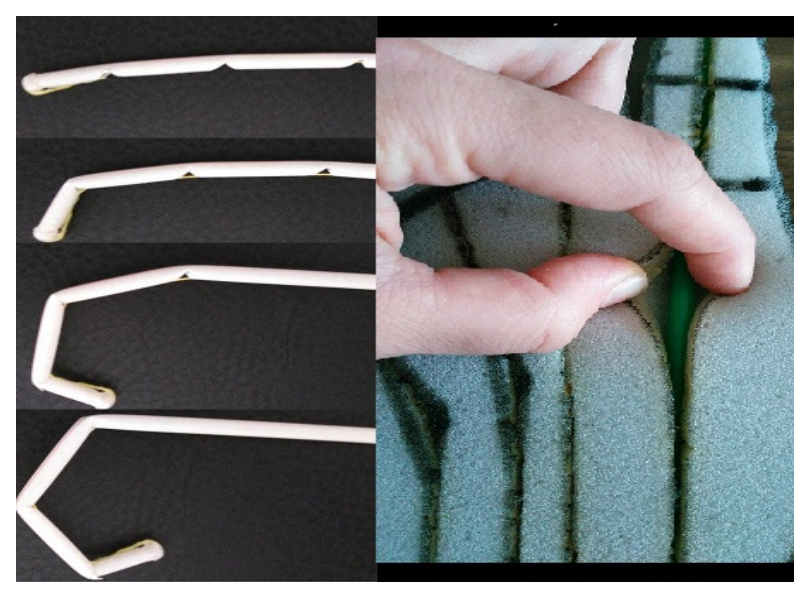

Figure 6. (a) Bending movement of the plastic tube guide with Kevlar (b) Guide in sponge hand

4 .Creating bending cutouts in sponge hand surface: After placement of the guides, joint lines are drawn with the same coordination of the guides; cutouts are made by hot wire sponge cutter, these cutouts act like a joint. (Figure 7)
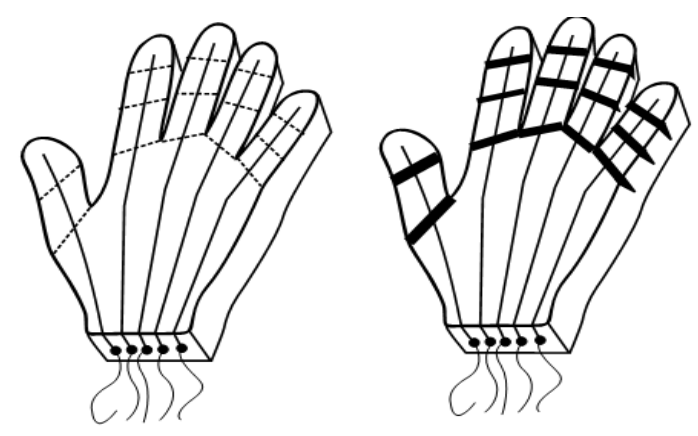

Figure 7. Creating cutouts

5. Connecting Kevlar strings to servo motors: Servo motors are connected to sponge hand's Kevlar strings and grasping application is performed (Figure 8). Sponge robotic hand is given in Figure 8.

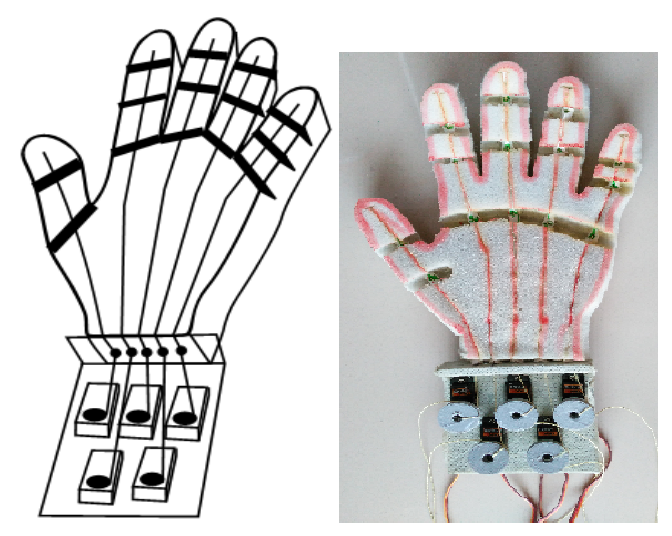

Figure 8. Connecting servo motors 
International Journal of Biomedical Engineering and Science (IJBES), Vol. 3, No. 4, October 2016

\section{CONCLUSION AND DISCUSSION}

In the light of literature, previous robotic hand designs are mostly made of rigid materials. Nowadays, soft materials are preferred to be used especially for rehabilitation and prosthetic hands, because of the compliance with the human body and grasping ability. In this study we designed a soft robotic hand with sponge as named 'Sponge Robotic Hand'. We gave all of the manufacturing stages and parameters of the sponge hand.

Some of the advantages of the sponge hands are

- With a sponge prosthetic hand, because of the sponge's compliance, you can wear all types of the glove on it. Glove can be a rigid woven fabric or flexible knitted fabric.

- Sponge hand is lighter than other plastic hands which have the same dimensions.

- Sponge hand's cost of production is lower than the other prosthetic hands.

- Sponge hand's personalized production is easier.

- In sponge robotic hand, more than one guide is can be used and different guide designs can provide different bending movements. Thus it can be closer to a real hand

In future studies, grasping and bending experiments will be done with different cutouts and sizes.

\section{ACKNOWLEDGEMENT}

This study was supported by UBAP06 2015/TP005 Project, Usak University.

\section{REFERENCES}

1. B. Siciliano, O. Khatib, eds., Springer handbook of robotics, Springer, Berlin, 2008.

2. Comparison of Production Methods in Soft Robotic, in: Universal Researchers, 2015. doi:10.17758/UR.U0915114.

3. J.A. Gallego, E. Rocon, J. Ibanez, J.L. Dideriksen, A.D. Koutsou, R. Paradiso, M.B. Popovic, J.M. Belda-Lois, F. Gianfelici, D. Farina, others, A soft wearable robot for tremor assessment and suppression, in: Robot. Autom. ICRA 2011 IEEE Int. Conf. On, IEEE, 2011: pp. 2249-2254. http://ieeexplore.ieee.org/xpls/abs_all.jsp?arnumber=5979639 (accessed November 13, 2014).

4. S.A. Morin, R.F. Shepherd, S.W. Kwok, A.A. Stokes, A. Nemiroski, G.M. Whitesides, Camouflage and Display for Soft Machines, Science. 337 (2012) 828-832. doi:10.1126/science.1222149.

5. C.D. Onal, D. Rus, Autonomous undulatory serpentine locomotion utilizing body dynamics of a fluidic soft robot, Bioinspir. Biomim. 8 (2013) 026003. doi:10.1088/1748-3182/8/2/026003.

6. A.D. Marchese, C.D. Onal, D. Rus, Autonomous Soft Robotic Fish Capable of Escape Maneuvers Using Fluidic Elastomer Actuators, Soft Robot. 1 (2014) 75-87. doi:10.1089/soro.2013.0009.

7. K.B. Shimoga, A.A. Goldenberg, Soft Robotic Fingertips: Part I: A Comparison of Construction Materials, Int. J. Robot. Res. 15 (1996) 320-334. doi:10.1177/027836499601500402.

8. J.D. Crisman, C. Kanojia, I. Zeid, Graspar: A flexible, easily controllable robotic hand, Robot. Autom. Mag. IEEE. 3 (1996) 32-38.

9. K.J. DeLaurentis, C. Mavroidis, C. Pfeiffer, Development of a shape memory alloy actuated robotic hand, in: 7th Int. Conf. New Actuators ACTUATOR 2000 Brem. Ger. June, 2000: pp. 1921.

http://engineering.nyu.edu/mechatronics/Control_Lab/bck/Padmini/Nano/Mavroidis/act2000.pdf (accessed April 4, 2016).

10. L.L. Howell, Compliant mechanisms, Wiley, New York, 2001.

11. D.D. Wilkinson, M.V. Weghe, Y. Matsuoka, An extensor mechanism for an anatomical robotic hand, in: Robot. Autom. 2003 Proc. ICRA03 IEEE Int. Conf. On, IEEE, 2003: pp. 238-243. http://ieeexplore.ieee.org/xpls/abs_all.jsp?arnumber=1241602 (accessed April 4, 2016). 
International Journal of Biomedical Engineering and Science (IJBES), Vol. 3, No. 4, October 2016

12. F. Lotti, P. Tiezzi, G. Vassura, L. Biagiotti, G. Palli, C. Melchiorri, Development of UB hand 3: Early results, in: Robot. Autom. 2005 ICRA 2005 Proc. 2005 IEEE Int. Conf. On, IEEE, 2005: pp. 4488-4493. http://ieeexplore.ieee.org/xpls/abs_all.jsp?arnumber=1570811 (accessed April 4, 2016).

13. R. Cabás, L.M. Cabas, C. Balaguer, Optimized design of the underactuated robotic hand, in: Robot. Autom. 2006 ICRA 2006 Proc. 2006 IEEE Int. Conf. On, IEEE, 2006: pp. 982-987. http://ieeexplore.ieee.org/xpls/abs_all.jsp?arnumber=1641837 (accessed April 4, 2016).

14. S. Takamuku, G. Gomez, K. Hosoda, R. Pfeifer, Haptic discrimination of material properties by a robotic hand, in: Dev. Learn. 2007 ICDL 2007 IEEE 6th Int. Conf. On, IEEE, 2007: pp. 1-6. http://ieeexplore.ieee.org/xpls/abs_all.jsp?arnumber=4354057 (accessed April 4, 2016).

15. C. Gosselin, F. Pelletier, T. Laliberte, An anthropomorphic underactuated robotic hand with 15 dofs and a single actuator, in: Robot. Autom. 2008 ICRA 2008 IEEE Int. Conf. On, IEEE, 2008: pp. 749-754. http://ieeexplore.ieee.org/xpls/abs_all.jsp?arnumber=4543295 (accessed April 4, 2016).

16. R.D. Schraft, G. Schmierer, Service robots, A K Peters, Natick, MA, 2000.

17. B. Rosén, H.H. Ehrsson, C. Antfolk, C. Cipriani, F. Sebelius, G. Lundborg, Referral of sensation to an advanced humanoid robotic hand prosthesis, Scand. J. Plast. Reconstr. Surg. Hand Surg. 43 (2009) 260-266. doi:10.3109/02844310903113107.

18. J.-Y. Nagase, N. Saga, T. Satoh, K. Suzumori, Development and control of a multifingered robotic hand using a pneumatic tendon-driven actuator, J. Intell. Mater. Syst. Struct. 23 (2012) 345-352. doi:10.1177/1045389X11420590.

19. J.T. Belter, A.M. Dollar, Novel differential mechanism enabling two DoF from a single actuator: Application to a prosthetic hand, in: Rehabil. Robot. ICORR 2013 IEEE Int. Conf. On, IEEE, 2013: pp. 1-6. http://ieeexplore.ieee.org/xpls/abs_all.jsp?arnumber=6650441 (accessed April 5, 2016).

20. R. Deimel, O. Brock, A compliant hand based on a novel pneumatic actuator, in: Robot. Autom. ICRA 2013 IEEE Int. Conf. On, IEEE, 2013: pp. 2047-2053. http://ieeexplore.ieee.org/xpls/abs_all.jsp?arnumber=6630851 (accessed March 14, 2016).

21. P. Polygerinos, S. Lyne, Z. Wang, L.F. Nicolini, B. Mosadegh, G.M. Whitesides, C.J. Walsh, Towards a soft pneumatic glove for hand rehabilitation, in: Intell. Robots Syst. IROS 2013 IEEERSJ Int. Conf. On, IEEE, 2013: pp. 1512-1517. http://ieeexplore.ieee.org/xpls/abs_all.jsp?arnumber=6696549 (accessed November 12, 2014).

22. K.C. Galloway, P. Polygerinos, C.J. Walsh, R.J. Wood, Mechanically programmable bend radius for fiber-reinforced soft actuators, in: Adv. Robot. ICAR 2013 16th Int. Conf. On, IEEE, 2013: pp. 1-6. http://ieeexplore.ieee.org/xpls/abs_all.jsp?arnumber=6766586 (accessed November 12, 2014).

23. P. Maeder-York, T. Clites, E. Boggs, R. Neff, P. Polygerinos, D. Holland, L. Stirling, K. Galloway, C. Wee, C. Walsh, Biologically Inspired Soft Robot for Thumb Rehabilitation, J. Med. Devices. 8 (2014) 020933.

24. A.H. Al-Timemy, A. Brochard, G. Bugmann, J. Escudero, Development of a Highly Dexterous Robotic Hand with Independent Finger Movements for Amputee Training, in: A. Natraj, S. Cameron, C. Melhuish, M. Witkowski (Eds.), Auton. Robot. Syst., Springer Berlin Heidelberg, Berlin, Heidelberg, 2014: pp. 291-293. http://link.springer.com/10.1007/978-3-662-43645-5_30 (accessed April 5, 2016).

25. A.De Beir, E. Caspar, F. Yernaux, P.M. Da Saldanha da Gama, B. Vanderborght, A. Cleermans, Developing new frontiers in the Rubber Hand Illusion: Design of an open source robotic hand to better understand prosthetics, in: Robot Hum. Interact. Commun. 2014 RO-MAN 23rd IEEE Int. Symp. On, IEEE, 2014: pp. http://ieeexplore.ieee.org/xpls/abs_all.jsp?arnumber=6926368 (accessed April 5, 2016).

26. Kevlar, Wikipedia $\quad$ Free $\quad$ Encycl. (2016). https://en.wikipedia.org/w/index.php?title=Kevlar\&oldid=707271431 (accessed April 10, 2016). 